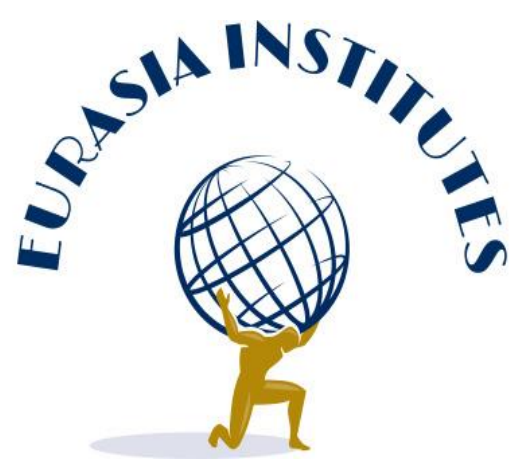

DOI: 10.47669/PSPRP-2-2020

\title{
What Has Changed? The Dynamics of Post-Maidan Nation-Building in Ukraine
}

\section{Aram Terzyan}

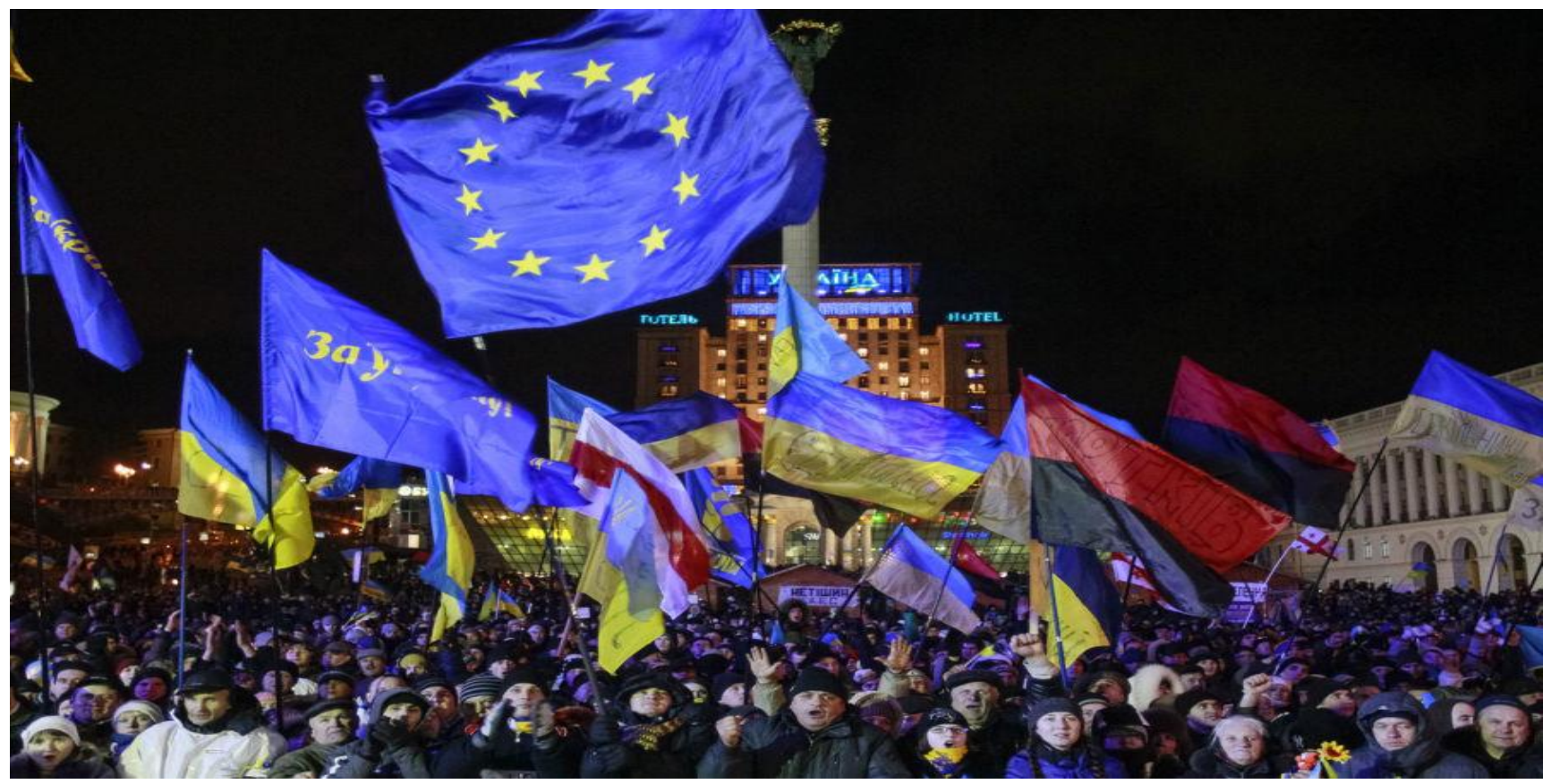

Center for East European and Russian Studies 


\begin{abstract}
The 2014 Maidan Revolution has been largely viewed as the most radical attempt at defying post-Soviet order since the break-up of the Soviet Union. A question remains as to what extent the economic and political problems causing the revolution have been addressed during post-Maidan nation-building. Even though some observers have been critical of lingering authoritarian and corrupt practices, Volodymyr Zelensky's rise to power in 2019 seems to give a new impetus to political and economic reforms across the country. While, the intensifying anti-corruption efforts and progress on economic reforms (including energy, tax, public procurement and land reforms) have sparked optimism, the Ukrainian government's ability to successfully overcome the authoritarian legacy and to reinforce the institutional foundations of nation-building seem critical to shifting the reform process into a higher gear.
\end{abstract}

Keywords: Ukraine, Maidan Revolution, nation-building, anti-corruption, Europeanization.

\title{
Introduction
}

This paper focuses on the dynamics of economic and political reforms in Ukraine after the 2014 Maidan Revolution. Some are saying that "a new Ukraine was born on the Maidan," by means of demonstrations that not only brought a new government to power but changed the people and their outlook" (Diuk, 2014).

Essentially, the Maidan Revolution became a demonstration of Ukraine's strong resilience and persistence in asserting its European orientation. Yet, the "choice for Europe" does not smoothly translate into substantial Europeanization and democratic consolidation. Clearly (2016) notes that the Orange Revolution in Ukraine would provide grounds for great optimism and get hailed as triumph of democracy over authoritarianism - leading Ukraine to its rightful place as a free, democratic state in Europe (Clearly, 2016). Yet, the powerful oligarchy's resistance to reforms, would leave Ukrainians disappointed.

Some observers have pointed to a series of hindrances to post-Maidan democratic consolidation, ranging from the constraining effects of authoritarian legacy to the residual influence of oligarchy (Pleines, 2016; Bayramov and Marusyk, 2019). It is argued that a series of domestic factors (the weakness of institutions and civic organizations) and external elements (the war with Russia) have been considerably impeding post-revolution state- building in Ukraine, thus leaving the key problems that hinder national development unsolved (Kuczyńska-Zonik and Kowalczyk, 2016).

Nevertheless, Volodymyr Zelensky's rise to power in 2019 seems to introduce a new model of democratic governance, as opposed to the system, through which five consecutive presidents had come up. While his reform agenda has provided grounds for optimism, the question remains as to whether it will make a significant difference, by defeating systemic corruption, completing deoligarchisation and, thus transforming the country into a consolidated democracy. 
Overcoming the Authoritarian Legacy? Understanding Regime Change in Ukraine

This paper contributes to existing literature on Ukraine's post-revolution state-building through exploring the core dynamics behind Ukraine's post-Maidan trajectory 'from revolution to reform'. It focuses on both challenges, stemming chiefly from lingering effects of corruption and oligarchy, and opportunities, associated with Ukraine's considerable approximation towards the European Union. It addresses the following research question: What are the core outcomes of the Maidan Revolution in terms of economic and political reforms?

This paper is an in-depth case analysis, that uses policy analysis to examine the core dynamics of Ukraine's post-Maidan transformation.

\section{The path to democratic governance and a vibrant civil society}

One of the intriguing questions regarding post-revolution state-building in Ukraine is whether and to what extent the domestic change has led to fundamental democratic reforms across the country. The answer to this question has a great deal to do with the interests, perceptions and preferences of powerful local actors, often called the 'gatekeeper elites' (Kakachia et al., 2019, p. 4).

According to the survey conducted by Razumkov Centre for Economic and Political Studies, the most trusted government and public institutions are the president of Ukraine (79\% of respondents), the Armed Forces of Ukraine (74\%), the least trusted ones are the judicial system as a whole (72\%), local courts (66\%), political parties (63\%), as well as anti-corruption agencies (Uniian, 2019). This survey suggests that there is a long way ahead to shift from charismatic appeal or rule to well-established institutions that translate leader's vision into policies sustained by appropriate structures, rules, and procedures.

While, there is no denying that Ukraine is undergoing large-scale reforms during Zelensky's presidency, Inna Sovsun, a member of the Ukrainian opposition party Holos (Voice) notes that the centralization of power remains a significant issue as "we don't know who the next president will be" (Euronews, 2020).

As a matter of fact, Ukraine finds itself in an unprecedented situation, where the president's party holds the majority in parliament and, therefore, can introduce and pass laws without compromise.

Volodymyr Zelensky capitalized on his huge popularity and through snap elections significantly consolidated his power. He is largely treated as "savior" capable of turning Ukraine's plight around and putting it on the path to prosperity and democracy. Meanwhile, the concentration of power in the hands of a charismatic leader is fraught with possible abuses in the absence of powerful opposition and vibrant civil society. There has been a strong tendency in Zelensky's discourse to style his regime as "people's government" or "people's servant" that introduce a new 
form hyper-democratic interaction between state and society (Zelensky, 2019). The Ukrainian President has tended to distance himself from his predecessors and other presidents due to his resolve to bring people to power "who will serve the people" (Zelensky, 2019).

Essentially, like many other post-Soviet countries, Ukraine is faced with "party presidentialization" syndrome - remarkable indicator of an insufficient institutionalization of party politics. The inherent unsustainability and instability of the Ukrainian regime has been vividly manifested in mass mobilizations against Leonid Kuchma regime in the 2004 Orange Revolution, and similarly by the mass protests that led to the collapse of Viktor Yanukovych regime in 2014 (Sedelius, 2014).

Meanwhile, Ukraine's party system does not seem stable enough to support the democratic consolidation of the country. Ukraine's post-Soviet institutional legacy, characterized by lack of legitimacy, stability and durability, would be long unfit to serve societal interests, thus obstructing country's democratic development (Ribiy, 2013).

Studies show that despite the advances in democratization following the Maidan Revolution, the essential features of Ukraine's party system have not undergone significant changes. As a result, the institutional bases of the Ukrainian party-political landscape and parliamentary politics have not been solidified (Fedorenko et al., 2016). The factors hindering institutionalization of political parties, include their organizational weakness, characterized by uncertain ideological platforms, frequent name changes, financing, lack of accountability and poor communication with their voters. Not surprisingly, there has been low level of trust in and identification with political parties across the Ukrainian society (Rybiy, 2013, p. 402).

The lack of ideologically - driven political parties has led to a situation, where the political and ideological preferences of Ukrainians are ambiguous and most people have a difficulty identifying themselves either with left or right parties (Balyuk, 2018). Moreover, an all-Ukrainian survey suggests that considerable part of respondents (nearly half of them) would be willing to vote for a newly created political party, while a third of them find party members critical to determining what party they would vote for (Balyuk, 2018). That said, when determining their political preferences, Ukrainians tend to focus more on individuals rather than on ideologies or party programs.

Overall, low level of trust in political parties has not been uncommon in post-Soviet countries. Decades of monopolization of the electoral arena by communist parties would be followed by the emergence of populist parties, thus casting a negative light on political parties across post-Soviet societies.

While civic activism has been pivotal to the 2014 Maidan Revolution a question remains as to if the civil society has evolved into an agent of democracy in Ukraine. Way notes that the demonstrations leading the revolution "showed the Orange Revolution was not a one-time fairy tale, 
Overcoming the Authoritarian Legacy? Understanding Regime Change in Ukraine

but a feature of Ukraine. Civil society exists" (Way, 2014, p. 35). Nevertheless, he suggests that it would be misleading to treat the successful actions by protesters or even civil society representatives per se as s shift in a robust or "emerging" civil society (p. 41). Thus, the question remains as to if protests are organized by well-established and institutionalized organizations, or do groups emerge spontaneously out of the protests themselves?

In this regard Smagily and Diuk note that civil society organizations and activists need to move beyond the victory in the street and pursue victory in town halls and elections (Smagily, 2017) with the growing realization that "the Maidan" now needs to be in people's minds and behavior rather than in downtown Kyiv (Diuk, 2014, p. 89) .

Alternatively, some observers posit that civil society is not always good for democracy, especially in the context of fragile national institutions that might be adversely affected by associational activity with ensuing societal fragmentation (Way, 2014, p. 41). In Ukraine, non-state actors have tended to divide along regional lines. Meanwhile at a time when the country is faced with tremendous threats, such divisions may be immensely harmful. Therefore, strong national institutions are deemed instrumental in mitigating the adverse effects of fragmentation, especially when facing huge associational activities (p. 42).

Clearly, while the steps towards a value-based civil society advancement has sparked optimistic commentaries, the growing activism of marginal far-right groups, including 'Svoboda', the National Corpus, the Right Sector, as well as extremist groupings such as OUN Volunteer Movement, Brotherhood and others, that would raise concerns across the Ukrainian civil society and beyond . While their attempts of moving from margins to mainstream have not resonated with the Ukrainian population, they have consistently tried to impose their radical agenda on the Ukrainian society and spread their illiberal ideas (Likhachev, 2018). More specifically, the extremist groups would specifically target left-wing, liberal activists and human rights defenders, as well as ethnic and religious minorities stressing the necessity of "cleaning" the public space of everything that they deem harmful to the nation or unacceptable in the face of the ongoing war (Likhachev, 2018). Essentially, the conflict with Russia has provided a fertile ground for their rebranding as "patriots" and for somehow legitimizing their activities.

Studies show, that the involvement of Ukrainian far-right organizations in Maidan protests would prompt the Russian media and politicians to portray the Maidan as a "fascist coup," with the activists and the new government being labelled as nationalistic, extremist, and xenophobic, that are on the 'wrong side of history' (Likhachev, 2018; Gaufman, 2017).

Nevertheless, despite their "radicalizing effect" on some nationalistic segments of Ukrainian society, none of the far-right parties managed to overcome the passing barrier to enter the Parliament. 
The electoral alliance comprised of Svoboda, the Right Sector and National Corps won only 2.15 percent of the vote (Vorobiov, 2020).

While there has been negligible public support for far-rightists and they are highly unlikely to move from the streets to the halls, the advancement of vibrant civil society organizations is critical to raising the Ukrainian society's immunity to extremism and illiberal ideas.

Studies show the Ukrainian civil society has been consistent in terms of standing up for its "choice of Europe" even after the Maidan Revolution. More specifically, civil society organizations have been playing an active role in the promotion and oversight of reforms leading to the implementation of the Association Agreement with the European Union. The largest and most visible reform network - the Reanimation Package of Reforms (RPR) has brought together NGOs, reform groups and experts, who develop, promote, and in some cases even implement judicial, anticorruption and economic changes. The underlying objective of the RPR is supporting implementation of reforms, to build an independent, consolidated, democratic, state with a consolidation of civil society (RPR. 2019). Remarkably, on the eve of the 2019 presidential and parliamentary elections RPR prepared a "to do list" for the president's reform agenda aimed at ensuring the new government's consistent commitment to the reform path and, more specifically, to the successful implementation of the Association Agreement (Khomei, 2020). Such initiatives suggest that the Ukrainian civil society organizations move beyond the victory in the street and pursue victory in town halls and elections (Smagliy, 2017).

The EU reports would give credit to the Ukrainian civil society that "continues to play a very active role in the promotion, design and oversight of reforms, especially in the areas of anticorruption, judiciary, human rights, decentralization, energy, and healthcare... Ukrainian civil society organizations continued to take an active part in the Eastern Partnership Civil Society Platform and the EU-Ukraine Civil Society Platform foreseen by the Association Agreement" (European Commission, 2019).

While, the advancement of civil society organizations provides a ground for optimism, the consistent development of their adequate institutional and professional capacity and networks to influence policy making and its implementation remains a significant task.

Studies show that the path to a vibrant and consolidated civil society has two main dimensions. The first dimension comes down to the changes in the nature of civil society relations with the state and society and its potential and ability to induce reform, or what is often referred to as "change on the outside" (Shapovalova and Burlyuk, 2018). This has much to do with increasing their impact on public policy and practice, not least through engaging more with their constituencies and improving their interaction with public institutions and actors. It has not been uncommon for post-Soviet 
Overcoming the Authoritarian Legacy? Understanding Regime Change in Ukraine

societies to treat civic associations as threat to the power and stability of the state together with the conviction that the state bears the responsibility for the wellbeing of the Society (Terzyan, 2020).

A survey shows that most respondents welcome the state's active involvement in issues like social guarantees and display inclinations toward paternalism, while neglecting the responsibility of society members for addressing such problems. Interestingly, despite their distrust of state institutions, Ukrainians still prefer to delegate the function of wealth distribution to the state (Balyuk, 2018, p. 24).

Similarly, surveys show that there is a somewhat paternalistic attitude towards European values, in Central and especially Southern and Eastern Ukraine. The respondents would often claim that it is the government's duty to ensure human rights and everyone's equality before the law, as well as to create opportunities for self-realization, etc. Overall, respondents in Eastern Ukraine are more inclined to believe that values shared by EU-Europeans and most Ukrainians should be implemented from the outside and installed by the state (Buhbe, 2017). By contrast, respondents in Western Ukraine have a better understanding of the values shared by the EU-Europeans, while acknowledging the duties of ordinary citizens (Buhbe, 2017). Clearly, greater engagement and effective communication with various social groups is pivotal to breaking down public misperceptions of CSOs and their activities. Thus, the "change on the outside" is critical to reducing the apathy of the wider public and stimulating their political participation.

The second critical dimension is "change on the inside," related to the nature of civil society per se i.e. with the way it is organized and operates. This in turn, has a great deal to do with the development of adequate institutional and professional capacity in civil society organizations and networks as a vital tool for influencing policy making. The institutional development at the organizational level includes building organizational capacities for governance, decision-making, and conflict management, as well as clarifying organizational identity, values, and strategy of impact. The latter is of crucial relevance as a lot of CSOs in Ukraine were established in response to certain needs or funding priorities with no predefined mission, strategic plans, and organization structure (Terzyan, 2020). That said, they were doomed to failure in terms of addressing the specific needs of their constituencies.

In sum, as a well-informed observer aptly notes "strong, autonomous societal organizations and networks may not always be democracy's allies, but their absence is almost always democracy's enemy" (Evans, 2011, p. 46).

Therefore, it is hard to underestimate the importance of robust CSOs in terms of Ukraine's democratic consolidation. 


\section{Economic reforms and Europeanization}

The question whether the Maidan Revolution has produced significant reforms, goes into determining its implications for country's economic recovery. As a matter of fact the hardships of post-Soviet transition, compounded by oligarchs' outsized influence over the Ukrainian economy have long condemned the Ukrainian population to lack of economic opportunities, unemployment and poverty. Therefore, by standing up for their "European choice," the Ukrainian people hoped to head down the path to fundamental economic reforms and prosperity.

Indeed, Ukraine's subscription to the Association Agreement with the EU has preseted huge opportunities for large-scale economic reforms. It includes a comprehensive agenda for bilateral cooperation and contains binding, rules-based provisions aiming at the export of EU rules and values (Petrov and Elsuwege, 2016).

In 2016-19, the Poroshenko administration took considerable macroeconomic stabilization measures, resulting in the budget deficit reduction to 2 percent of GDP, while inflation fell to 5 percent. Moreover, public debt dropped from 80 percent of GDP in 2016 to 52 percent of GDP (Aslund, 2020).

Studies show that Ukraine performed best in implementing reforms when it faced precise demands from the EU (Fedorneko, 2017). More specifically, Ukraine has made considerable progress on reforms in energy, public procurement, public administration, and law enforcement sectors (European Parliament, 2017). Energy security-related issues have occupied a prominent position in the EU-Ukraine partnership. In essence, Poroshenko's government placed a special emphasis on reforming the gas sector, as a critical step to build resilience against Russian "energy weapon" and made crucial strides in cutting subsidies on natural gas - previously misused by Ukranian elites to ensure electoral support (Forbes, 2019).

The EU has been supporting Ukrainian government's efforts to reform country's gas sector focusing specifically on reinforcing Ukrainian gas storage system and developing a business model for the new transmission system operator (European Neighbours, 2018). The EU reports note that in terms of legal approximation, Ukraine has adopted strategies and implemented laws on energy performance, covering the issues of energy efficiency, fuel diversification, renewable energy and environmental protection (European Commission, 2018, pp. 14-16). Namely, the adoption and successful application of the new Law on Auctioning of Support for Renewables in April 2019, foster further investments in the sector, including from EU and foreign companies. As a result, the proportion of electricity produced from renewable sources has increased from below $2 \%$ in 2018 to 5\% in mid-2019 (European Commission, 2019, p. 19). 
Overcoming the Authoritarian Legacy? Understanding Regime Change in Ukraine

The EU has promoted energy sector reform in Ukraine through the EU4Energy initiative which includes a four-year EU technical assistance programme (2016-2020). The programme specifically focuses on legal approximation with Eastern Partnership countries, with the view to creating electricity and gas markets promoting energy efficiency (EU4Energy, 2019). The bilateral energy partnership arrived at a major accomplishment in June 2019, when the Verkhovna Rada of Ukraine ratified the renewed energy Annex XXVII to the Association Agreement between Ukraine and the European Union (Government Portal, 2019). This envisages EU energy rules transfer to Ukraine, with the view to the latter's integration into the EU's internal energy market (Government Portal, 2019). Indeed, the ratification of the energy annex is of crucial relevance in terms of Ukraine's compliance with the EU requirements and policies.

Nevertheless, Bayramov and Marusyk (2019) note that, despite remarkable natural gas and electricity reforms having been undertaken, Ukraine still has significant work to do in order secure its energy future (Bayramov and Marusyk, 2019).

Namely, implementation of the electricity sector reform remains challenging in the current oligopolistic market structure. The aim is to move from an overly regulated single buyer model with cross-subsidies to a competitive market in line with EU legislation (European Commission, 2019, p. 18).

Some observers would be critical of the depth of Ukraine's energy reforms, contending that

despite the Ukrainian leadership's proclaimed openness to profound Europeanization in the field of energy, the pre-existing, deep-seated preferences of those elites have perpetuated the opaque gas trading system. Overall, while the ongoing reforms provide grounds for optimism, Ukraine's energy future considerably depends on Zelensky's government's ability and political will to fully implement the EU-backed energy reforms (Bayramov and Marusyk, 2019).

With regard to broader economic reforms, it is noteworthy that as a result of provisional application of the AA/DCFTA the EU has become Ukraine's largest trade partner by far, representing 42.4\% of total exports in the first seven months of 2019 (European Commission, 2019, p. 16).

In the first seven months of 2019 exports from Ukraine to the EU increased by $7.8 \%$ year-onyear, while imports from the EU increased by 9\% year-on-year (European Commission, 2019, p. 16). Moreover, Ukraine has improved its business environment in recent years, though this progress is stalling to some extent. According to the World Bank's Doing Business survey, Ukraine ranked 71th in 2018, which was an improvement from 76th in 2018, and 142 ${ }^{\text {nd }}$ in 2010 (European Commission, 2019, p. 12).

Remarkably, since 2014, the EU and the European Financial Institutions have mobilized a package of more than $€ 15$ billion in grants and loans to support the reform process, with strong 
conditionality on continued progress (EEAS, 2019a).

The Ukrainian government has made considerable progress on EU approximation in the areas of trade, customs, SPS, intellectual property, and social policy (European Commission, 2018). Besides, Ukraine has marked accomplishments in public procurement reforms, introducing a higher level of transparency on budget transactions and beneficiaries of procurements. In December 2015, the Verkhovna Rada adopted the law 'On Public Procurement', and a Public Procurement Reform Strategy (Roadmap) was adopted in February 2016 to harmonize legislation with the EU acquis (European Parliament, 2017, pp. 20-21). Moreover, Ukraine has introduced in the public eprocurement system "ProZorro" new functionalities, such as framework agreements, developed a professional standard for the public procurement specialists, along with implementing the pilot Centralised Procurement Body at national level (European Commission, 2019, p. 17). Notably, the Ukrainian government has prioritized tax reforms and strived to simplify tax systems. More specifically, Poroshenko proposed the "new philosophy" in taxation to simplify tax for small businesses and attract investors. The Ukrainian government's decision to shift the corporate tax burden from company profits to distributions has been welcomed by investors from Europe (Lomas, 2018). Overall, the tax system reforms in Ukraine include: implementation of a cap and eventual removal of agricultural subsidies; implementation of a centralized database of locally set tax rates (land and property taxes); introduction of uniform reporting on profit for corporations; elimination of 18 percent tax on dividends paid by those that do not pay profit tax; elimination of 15 percent tax on interest paid on syndicated loans, etc. These reforms, among other accomplishments, have led to the elimination of an export tax on grains and oilseeds as well as that of 29 different permits and licenses mainly in agriculture, coupled with improvement of land property rights (Atlasnetwork, 2018).

Zelensky's government has been paying considerable attention to land reform, along with the wider reforms required to attract foreign direct investment into the agriculture sector, support large and small farmers and increase efficiencies.

Investments are vitally important now, given that because of COVID-19, Ukraine's GDP is predicted to shrink 5-6 percent. There is broad consensus among observers that it is critical to provide a level playing field and a healthy business environment conducive to foreign investments in the agriculture sector. That said, no investors whether foreign or domestic would consider investing in an asset that could be easily taken away from them by corporate raiders. Clearly, addressing such concerns has much to do with effective implementation of large-scale anti-corruption measures that, among others, would immensely benefit country's business environment (Chantam House, 2020). 
Overcoming the Authoritarian Legacy? Understanding Regime Change in Ukraine

\section{Fight against corruption and law enforcement reforms}

One of the intriguing questions revolving around post-revolution state-building in Ukraine is whether and to what extent the domestic change will produce significant outputs in terms of eradicated deeply rooted corrupt and authoritarian practices.

Poroshenko's government significantly reduced the corruption, particularly in the gas, banking, and government procurement sectors. As a sign of moving the fight against corruption to the highest possible policy agenda, the Ukrainian government introduced the National AntiCorruption Bureau and the Specialized AntiCorruption Prosecutor's Office NABU as well as Specialized Anti-Corruption Prosecutor's Office (SAPO) established in 2015 with the participation of civil society and donor countries (OECD, 2017). Yet, the effectiveness of these institutions has been questioned by several observers, pointing to insufficiency of anti-corruption measures amidst unrelenting efforts by power groups to retain their outsized influence over law enforcement and justice (Gressel, 2019).

Moreover, there was little progress on the fight against judicial corruption. Even though the judicial reform was hailed by Poroshenko as "the mother of all reforms," (Jarabik and De Waal, 2018) there was not much to reinforce government's pledges of fundamental reforms. Poroshenko's steady decline as a political powerhouse significantly owed to his failure to eradicate corruption.

Meanwhile, Volodymyr Zelensky's promises of defeating rampant corruption resonated with Ukrainians, who placed a great deal of faith in his 'game-changing' agenda.

The Rada's first day was marked with the adoption of important pieces of anti-corruption legislation, including the removal immunity from prosecution for MPs and the proposal to provide the National Anti-Corruption Bureau of Ukraine (NABU) with the right to undertake autonomous surveillance (Emerson and Remzov, 2019). Moreover, Zelensky's anti-corruption efforts resulted in investigations and subsequent arrests of some of President Poroshenko's associates, including Oleg Hladkovsky, a top Defense official; a People's Front party MP and the former head of the Rada's defense committee Serhii Pashinsky; ex-deputy minister for the occupied territories Yuri Hrymchak; and Poroshenko Bloc MP Yaroslav Dubnevych, etc. Furthermore, Zelensky put the High AntiCorruption Court into action, that passed a bill reinstating criminal liability for the illicit enrichment of officials (Minakov and Rojansky, 2019).

However, these arrests and investigations have not yet led to court rulings. The question remains if the anti-corruption measures will move beyond selective prosecution of former officials to the unequivocal application of "zero tolerance for corruption" principle.

This in turn comes down to the furtherance of democratic reforms, leading to the advancement of good governance practices and eradication of the systemic corruption, including particularly 
judicial corruption. While Poroshenko would previously hail the judicial reform as "the mother of all reforms" there was not much to reinforce government's pledges of fundamental reforms (New Eastern Europe, 2019). To rectify these shortcomings, President Zelensky embarked on judicial reforms. More specifically, he dismissed the High Qualification Council of Judges (the body responsible for attestation and selection of judges), announced plans to reload the Higher Council of Judges (the highest self-governance body of judges) and halved the number of Supreme Court judges (Sologoup, 2020). Remarkably, while the Venice Commission, an advisory body of the Council of Europe, praised Zelensky's government's judicial reform, it expressed concern over certain aspects of the reform, pertaining to "important issues of the rule of law" in Ukraine (Euronews, 2020). The Commission criticized the situation, where the politicians are seen to get too much power to determine whether the sitting judges remain in their position or not (Euronews, 2020).

Overall, the judicial reform remains as big challenge in the country, as its success is critical to breaking with the authoritarian legacy. Not surprisingly, while the European Parliament's report welcomes the ongoing comprehensive judicial reform, it also "regrets the extent to which the existing judicial system in Ukraine still remains ineffective, corrupt and politically dependent" (European Parliament, 2018).

It is noteworthy that Ukraine is the 126 least corrupt nation out of 180 countries, according to the 2019 Corruption Perceptions Index reported by Transparency International (Trading Economics, 2020).

Essentially, political elite's robust commitment to eradicating systemic corruption is indispensable. Although political will may not be sufficient, it is a necessary condition to combat corruption. The case of Romania demonstrates that the political will to defeat corruption may well make up the absence of a tradition of the rule of law and democracy. More specifically, the European Union pressure, along with the electoral pressure and the political will of the domestic political elite combined to ensure the establishment of the rule of law and defeating corruption in the Romanian judiciary between 1997 and 2006 (Ritsei, 2010).

In terms of broader rule of law reforms, there is much room for significant improvements in Ukraine's law enforcement authorities.

The Maidan Revolution has given a strong impetus to overcoming the post-communist policing legacy, plagued by corruption and authoritarian malpractices, and thus opened a space for democratic policing (Friesendorf, 2019). Kirsten Madison, Assistant Secretary of State for International Narcotics and Law Enforcement Affairs notes that the police reform has become the most significant in the transformation of the law enforcement agencies in Ukraine (Unian, 2018). The fact that Ukrainian patrol police, the KORD special forces unit, and the State Border Guard Service are 
Overcoming the Authoritarian Legacy? Understanding Regime Change in Ukraine

implementing advanced western standards prompted Madison to posit that police reform is one of the most striking elements of what modern Ukraine might look like (Unian, 2018).

A well-informed observer argues that in the case of Ukraine the keys to a successful and sustainable police reform in certain parts of the police have been: first, insulation of new police institutions from politicization and patrimonial staffing to ensure their independence and impartiality; and second, institutional design which mandates transparency mechanisms, accountability procedures and civilian oversight in the staffing, promotion and activity reporting of police (Pehlman, 2019). Clearly, the successful transformation of the Security Service of Ukraine (SUB) (the KGB successor) remains a critical part of broader law enforcement reforms. Gressel finds SUB's transformation critical to preventing it from further getting misused by incumbent authorities as a tool for coercing opposition (Gressel, 2019, pp. 11-15). Overall, the promotion of reform-minded law enforcement officials along with consistent fight against systemic corruption seems instrumental in achieving a breakthrough in law enforcement and broader democratic reforms.

\section{Conclusions}

This article contributes to the existing literature and ongoing debate regarding the anatomy of post-revolution state building in former Soviet Union countries, by examining the case of Ukraine.

Based on the previous discussion, there are three main concluding observations to make regarding Ukraine's post-Maidan transformation.

Firstly, and in terms of institutional foundations of post-Maidan state-building, one of the biggest challenges involves increasing the institutional capacities of political parties and civil society organizations. Insufficient institutionalization has led to "party presidentialization" - a situation where the voters tend to pay more attention to leaders, rather than to principles of political parties. While Zelensky remains immensely popular, the logic of democratic consolidation requires to shift from charismatic appeal or rule to well-established institutions that translate leader's vision into policies sustained by appropriate structures, rules, and procedures. Along with their institutional development, it is essential for civil society organizations to engage more with their constituencies, thus contributing to their democratic socialization. It has not been uncommon for post-Soviet societies to treat civic associations as threat to the power and stability of the state together with the conviction that the state bears the responsibility for the wellbeing of the Society. Not surprisingly, studies show inclinations toward paternalism across the Ukrainian society, coupled with misconceptions about civil society organizations. Therefore, civil society organizations have a critical mission of breaking down lingering misperceptions and transforming citizens from spectators into actors. 
Secondly, and in terms of economic reforms, Ukraine has made remarkable progress on tax and energy reforms, along with those in public procurement and public administration. The Ukrainian government has achieved considerable accomplishments in EU approximation in the areas of trade, SPS, intellectual property, customs, and social policy. Moreover, the provisional application of the AA/DCFTA has yielded significant results, by making the EU Ukraine's largest trade partner, as well as by improving country's business environment. To further the processes of reforms it is necessary to intensify anti-corruption efforts, especially at defeating judicial corruption.

Thirdly, and in terms of law enforcement reforms, the Ukrainian leadership has taken considerable strides in overcoming the post-communist policing legacy, and thus opened a space for democratic policing. Successful transformation of the Security Service of Ukraine (the KGB successor) remains a critical part of broader law enforcement reforms. The promotion of reformminded law enforcement officials along with consistent fight against systemic corruption seems instrumental in achieving a breakthrough in law enforcement reforms.

\section{References}

Åslund, A. (2020). Ukraine's Underrated Economy is Poised for a Strong 2020. Atlantic Council (retrieved from https://www.atlanticcouncil.org/blogs/ukrainealert/ukraines-underratedeconomy-is-poised-for-a-strong-2020/).

Atlas Network (2018). Tax code reform in Ukraine signals a major win fr Ueff (retrieved from https://www.atlasnetwork.org/news/article/tax-code-reform-in-ukraine-signals-a-major-win-forueff).

Balyuk, S., Klauning, N., Koval, M., Röthig, M. and L. Chetvertukhin (2018). The attitude of Ukrainians toward social democracy public opinion poll results (retrieved from http://library.fes.de/pdf-files/bueros/ukraine/14762.pdf ).

Bayramov, A. and Marusyk, Y. (2019). Ukraine's unfinished natural gas and electricity reforms: one step forward, two steps back. Eurasian Geography and Economics, 60(1), pp. 1-24.

Chaban, N. and O'loughlin, B. (2018). The EU's crisis diplomacy in Ukraine: The matrix of possibilities (retrieved from https://jia.sipa.columbia.edu/eus-crisis-diplomacy-ukraine-matrixpossibilities ).

Chantam House (2020). Land reform in Ukraine: Is Zelenskyy's government getting it right? (retrieved from https://www.chathamhouse.org/file/land-reform-ukraine-zelenskyys-governmentgetting-it-right).

Cleary, L. (2016). Half measures and incomplete reforms: the breeding ground for a hybrid civil society in Ukraine. Southeast European and Black Sea Studies, 16(1), pp. pp. 7-23.

Diuk, N. (2014). The Maidan and Beyond: Finding Ukraine. Journal of Democracy, 25(3), pp. 83-89.

Euronews (2020). Could Volodymyr Zelensky's proposed reforms lead to centralized power in Ukraine? (retrieved from https://www.euronews.com/2020/02/27/could-volodymyr-zelensky-sproposed-reforms-lead-to-centralised-power-in-ukraine).

European Commission (2018). Association implementation report on Ukraine (retrieved from https://eeas.europa.eu/sites/eeas/files/2018_association_implementation_report_on_ukraine.pdf ). 
Overcoming the Authoritarian Legacy? Understanding Regime Change in Ukraine

European Commission (2019). Association implementation report on Ukraine (retrieved from https://eeas.europa.eu/sites/eeas/files/swd_2019_433_f1_joint_staff_working_paper_en_v4_p1_105 6243.pdf).

European Neighbors (2018), Energy reforms: the challenge for Ukraine's gas market (retrieved from https://www.euneighbours.eu/en/east/eu-in-action/stories/energy-reforms-challenge-ukrainesgas-market).

European Parliament (2018). Report on the implementation of the EU Association Agreement with Ukraine (2017/2283(INI)) (retrieved from https://www.europarl.europa.eu/doceo/document/A8-2018-0369_EN.html).

Evans, A. B. (2011). The failure of democratization in Russia: A comparative perspective. Journal of Eurasian Studies, 2(1), 40-51.

Fedorenko, K. (2017). Ukraine four years after the Euromaidan (retrieved from https://www.wilsoncenter.org/blog-post/ukraine-four-years-after-the-euromaidan).

Fedorenko, K., Rybiy, O. and Umland, A. (2016). The Ukrainian party system before and after the 2013-2014 Euromaidan. Europe-Asia Studies, 68(4), pp. 609-630.

Forbes (2019). Energy Reform A Central Issue in Ukraine's Presidential Elections (retrieved from https://www.forbes.com/sites/rrapier/2019/03/27/energy-reform-a-central-issue-in-ukrainespresidential-elections/\#3fee5b554b46).

Friesendorf, C. (2019). Police reform in Ukraine as institutional bricolage. Problems of PostCommunism, 66(2), pp. 109-121.

Gaufman, E. (2015). World War II 2.0: Digital memory of fascism in Russia in the aftermath of EuroMaidan in Ukraine. Journal of Regional Security, 10(1), pp. 17-35.

Government Portal (2019). Verkhovna Rada adopted an updated energy Annex to the Association Agreement (retrieved from https://www.kmu.gov.ua/en/news/verhovna-rada-uhvalilaonovlenij-energetichnij-dodatok-do-ugodi-pro-asociaciyu).

Gressel, G. (2019). Guarding the Guardians: Ukraine's security and judicial reforms under Zelensky. ECFR Policy Brief (retrieved from https://www.ecfr.eu/page/-/guarding_the_guardians _ukraine_security_and_judicial_reforms_under_zelensky.pdf).

Khomei, O., (2019). Increasing the power of civil society in Ukraine" (retrieved from https://neweasterneurope.eu/2019/12/22/increasing-the-power-of-civil-society-in-ukraine/ ).

Kuczyńska-Zonik, A. and Kowalczyk, J. (2016). Nation-Building in Post-Maidan Ukraine. The Polish Quarterly of International Affairs, 3(2016), pp. 91-105.

Likhachev, V. (2015). The "Right Sector" and others: The behavior and role of radical nationalists in the Ukrainian political crisis of late 2013-Early 2014. Communist and PostCommunist Studies, 48(2-3), 257-271.

Likhachev, V., (2018). Far-right extremism as a threat to Ukrainian democracy.” Nations in Transit Brief (retrieved from https://freedomhouse.org/report/analytical-brief/2018/far-right-extremism-threat-ukrainiandemocracy ).

Lomas, U. (2018). Ukraine wins Praise for new corporate tax reform plans, 26 March (retrieved from https://www.tax-news.com/news/Ukraine_Wins_Praise_For_New_Corporate_Tax_ Reform_Plans_76627.html).

Minakov, M. and Rojansky, M. (2019). The first six months: An assessment of Zelensky's achievements. Wilson Center (retrieved from https://www.wilsoncenter.org /blog-post/the-first-sixmonths-assessment-zelenskyys-achievements). 
New Eastern Europe (2019). Ukrainian lessons, Armenian hopes, 19 September (retrieved from http://neweasterneurope.eu/2019/09/19/ukrainan-lessons-armenian-hopes/).

OECD (2017)

Anti-corruption reforms in Ukraine 4th round of monitoring of

the Istanbul anti-corruption

Action Plan

(retrieved

from http://www.oecd.org/corruption/acn/OECD-ACN-4th-Round-Report-Ukraine-ENG.pdf).

Pehlman (2019), Police reform in Ukraine since the Euromaidan: Police reform in transition and institutional crisis, CUNY Academic Works (retrieved from https://academicworks.cuny.edu/gc_etds/3073/).

Petrov, R. and Van Elsuwege, P. (2016), What does the Association Agreement mean for Ukraine, the EU and its Member States? A Legal Appraisal. Het eerste raadgevend referendum. Het EU-Oekraïne Associatieakkoord (Montesquieu Institute, Den Haag), pp. 71-88.

Pleines, H. (2016). Oligarchs and politics in Ukraine. Demokratizatsiya: The Journal of PostSoviet Democratization, 24(1), 105-127.

Reanimation Package of Reforms (2019) (retrieved from https://rpr.org.ua/en/about-us/).

Ristei, M. (2010). The politics of corruption: Political will and the rule of law in postcommunist Romania. Journal of Communist Studies and Transition Politics, 26(3), pp. 341-362.

Rybiy, O. (2013). Party system institutionalization in Ukraine. Demokratizatsiya, 21(3), pp. 401- 423.

Sedelius, T. (2015). Party presidentialization in Ukraine. In the Presidentialization of Political Parties (pp. 124-141). Palgrave Macmillan, London.

Shapovalova, N. and O. Burlyuk (2018). Civil society and change in Ukraine Post-Euromaidan: An introduction. In Civil Society in Post-Euromaidan Ukraine: from Revolution to Consolidation, 193, pp.11-38.

Smagliy, K. (2017). A wake up call for Ukraine's civil society. Kennan Cable, (25) (retrieved from https://www.wilsoncenter.org/publication/kennan-cable-no25-wake-call-for-ukraines-civilsociety).

Sologoup, I. (2020). Ukraine's top five 2020 reform priorities. Atlantic Council (retrieved from https://www.atlanticcouncil.org/blogs/ukrainealert/ukraines-top-five-2020-reform-priorities/).

Terzyan, A., Towards a vibrant civil society in Ukraine and Armenia. Emerging Europe (retrieved from https://emerging-europe.com/voices/towards-a-vibrant-civil-society-in-ukraine-andarmenia/) .

Unian (2018). Police reform most significant in transformation of law enforcement agencies in Ukraine: Madison (retrieved from https:/www.unian.info/society/10305807-police-reform-mostsignificant-in-transformation-of-law-enforcement-agencies-in-ukraine-madison.html).

Unian (2019). Almost 80\% of Ukrainians trust in Zelensky - poll, UNIAN (retrieved from https://www.unian.info/politics/10688256-almost-80-of-ukrainians-trust-in-zelensky-poll.html ).

Vorobiov (2019). Ukrainian Voters Upend their Parliament (retrieved from https://jamestown.org/program/ukrainian-voters-upend-their-parliament/).

Way, L. (2014). The maidan and beyond: civil society and democratization. Journal of Democracy, 25(3), pp. 35-43.

Zelensky (2019). Volodymyr Zelenskyy's inaugural address (retrieved from https://www.president.gov.ua/en/news/inavguracijna-promova-prezidenta-ukrayini-volodimirazelensk-55489). 